University of Wollongong

Research Online

Faculty of Engineering and Information

Faculty of Engineering and Information

Sciences - Papers: Part A

Sciences

$1-1-2013$

\title{
Effects of fouling on the stress-strain-degradation behaviour of rail ballast
}

Buddhima Indraratna

University of Wollongong, indra@uow.edu.au

Nayoma C. Tennakoon

University of Wollongong, nayoma@uow.edu.au

Sanjay Nimbalkar

University of Wollongong, sanjayn@uow.edu.au

Cholachat Rujikiatkamjorn

University of Wollongong, cholacha@uow.edu.au

Follow this and additional works at: https://ro.uow.edu.au/eispapers

Part of the Engineering Commons, and the Science and Technology Studies Commons

Research Online is the open access institutional repository for the University of Wollongong. For further information contact the UOW Library: research-pubs@uow.edu.au 


\title{
Effects of fouling on the stress-strain-degradation behaviour of rail ballast
}

\begin{abstract}
Ballast is most commonly used as a structural component of rail track due to its high load bearing capacity, resiliency and rapid drainage. However, ballast along coal freight corridors often becomes fouled due to spilling of coal from moving wagons, in addition to further track deterioration attributed to particle breakage and pumping of soft subgrade. Highly fouled ballast needs to be cleaned or replaced to maintain the desired track resiliency, load bearing capacity and the track alignment. In order to identify the risk associated with fouling, it is important to accurately assess the amount of fouling. In this paper, the use of Void Contaminant Index ( $\mathrm{VCl})$ compared to other mass-based indices is critically examined. A series of isotropically consolidated drained triaxial tests using a large scale cylindrical triaxial apparatus have been conducted on both clean and fouled ballast with varying $\mathrm{VCl}$ to assess the stress-strain and degradation characteristics. In accordance, a non-linear shear strength envelope for clean and fouled ballast is presented in a non-dimensional form. The maximum permissible train speed under different level of fouling is also proposed.
\end{abstract}

\section{Keywords}

strain, ballast, degradation, rail, effects, behaviour, fouling, stress

Disciplines

Engineering | Science and Technology Studies

\section{Publication Details}

Indraratna, B., Tennakoon, N. C., Nimbalkar, S. \& Rujikiatkamjorn, C. (2013). Effects of fouling on the stress-strain-degradation behaviour of rail ballast. In C. F. Leung \& S. H. Goh (Eds.), 18th Southeast Asian Geotechnical Conference (18SEAGC) cum Inaugural AGSSEA Conference (1AGSSEA) (pp. 587-592). Singapore: Research Publishing Services. 


\title{
EFFCTS OF FOULING ON THE STRESS-STRAIN-DEGRADATION BEHAVIOUR OF RAIL BALLAST
}

\author{
BUDDHIMA INDRARATNA \\ Professor of Civil Engineering, Director, Centre for Geomechanics and Railway \\ Engineering, Faculty of Engineering, University of Wollongong, Wollongong City, NSW \\ 2522, Australia, ARC Centre of Excellence in Geotechnical Science and Engineering, \\ Australia, email: indra@uow.edu.au \\ NAYOMA TENNAKOON \\ Research Fellow, Centre for Geomechanics and Railway Engineering, Faculty of \\ Engineering, University of Wollongong, Wollongong City, NSW 2522, Australia, ARC \\ Centre of Excellence in Geotechnical Science and Engineering, Australia \\ SANJAY NIMBALKAR \\ Research Fellow, Centre for Geomechanics and Railway Engineering, Faculty of \\ Engineering, University of Wollongong, Wollongong City, NSW 2522, Australia, ARC \\ Centre of Excellence in Geotechnical Science and Engineering, Australia \\ CHOLACHAT RUJIKIATKAMJORN \\ Senior Lecturer, Centre for Geomechanics and Railway Engineering, Faculty of Engineering, \\ University of Wollongong, Wollongong City, NSW 2522, Australia, ARC Centre of Excellence in \\ Geotechnical Science and Engineering, Australia
}

\begin{abstract}
Ballast is most commonly used as a structural component of rail track due to its high load bearing capacity, resiliency and rapid drainage. However, ballast along coal freight corridors often becomes fouled due to spilling of coal from moving wagons, in addition to further track deterioration attributed to particle breakage and pumping of soft subgrade. Highly fouled ballast needs to be cleaned or replaced to maintain the desired track resiliency, load bearing capacity and the track alignment. In order to identify the risk associated with fouling, it is important to accurately assess the amount of fouling. In this paper, the use of Void Contaminant Index (VCI) compared to other mass-based indices is critically examined. A series of isotropically consolidated drained triaxial tests using a large scale cylindrical triaxial apparatus have been conducted on both clean and fouled ballast with varying VCI to assess the stress-strain and degradation characteristics. In accordance, a non-linear shear strength envelope for clean and fouled ballast is presented in a non-dimensional form. The maximum permissible train speed under different level of fouling is also proposed.
\end{abstract}

\section{Introduction}

When ballast is fouled due to intrusion of fines from external sources, significant changes in the pore structure of the ballast occur resulting in reduced particle interlock and diminished void ratio. Numerous studies on granular materials through discrete element methods (Huang and Tutumluer 2011, Lim and McDowell 2005, Lu and McDowell 2006) and specific examination of the behaviour of clean ballast using discrete and continuum mechanics approaches (Indraratna et al. 2011) have been employed in the past. However, detrimental aspects of fouling on rail ballast have still not been assessed in detail. In this study, consolidated drained tests were conducted using a large-scale cylindrical triaxial apparatus to study the stress-deformation characteristics of 
clay fouled ballast under monotonic loading conditions. Fouling material is defined as particles smaller than $9.5 \mathrm{~mm}$ accumulated in the ballast voids (Selig and Waters 1994). Commonly used fouling indices include the Fouling Index, FI, the Percentage Fouling (Selig and Waters 1994) and the Percentage Void Contamination, PVC (Feldman and Nissen 2002). In the above mentioned indices, fouling materials that have significantly different specific gravities to the parent rock of ballast cannot be captured, leading to inaccurate volume estimations. $P V C$ is a direct measure of percentage of voids occupied by fouling particles on the volumetric basis and it provides better assessment of fouling. However, the volume of fouling material needs to be calculated after compaction (standard Proctor technique). This does not always represent the correct volume of fouling in the real track environment. In view of the above, a new parameter, Void Contaminant Index $(V C I)$ is proposed that can capture the role of different fouling materials and the corresponding void reduction as a modification to the $P V C$.

$$
V C I=\frac{V_{f}}{V_{v b}}
$$

where, $V_{f}$ is actual volume of fouling material accumulated in the voids of fouled ballast and $V_{v b}$ is the volume of voids in the clean ballast. By substituting the relevant soil parameters, $V C I$ can be expressed as (Indraratna et al. 2010, Tennakoon et al. 2012):

$$
V C I=\frac{\left(1+e_{f}\right)}{e_{b}} \times \frac{G_{s . b}}{G_{s . f}} \times \frac{M_{f}}{M_{b}} \times 100
$$

where, $e_{b}$ and $e_{f}$ are void ratios of clean ballast and fouling material, $G_{s b}$ and $G_{s f}$ are specific gravities of clean ballast and fouling material, $M_{b}$ and $M_{f}$ are mass of theclean ballast and fouling material respectively.

\section{Experimental Procedure}

A series of large-scale consolidated drained triaxial tests under static loading were carried out for a confining pressure range of $10-60 \mathrm{kPa}$. In the field, the confining pressure hardly exceeds $20 \mathrm{kPa}$ even under highly compacted states of angular ballast fragments. Due to the coarse particle sizes of ballast, a large-scale triaxial apparatus designed and built at the University of Wollongong that could accommodate a specimen of $600 \mathrm{~mm}$ in height and $300 \mathrm{~mm}$ in diameter was used (Figure 1). 


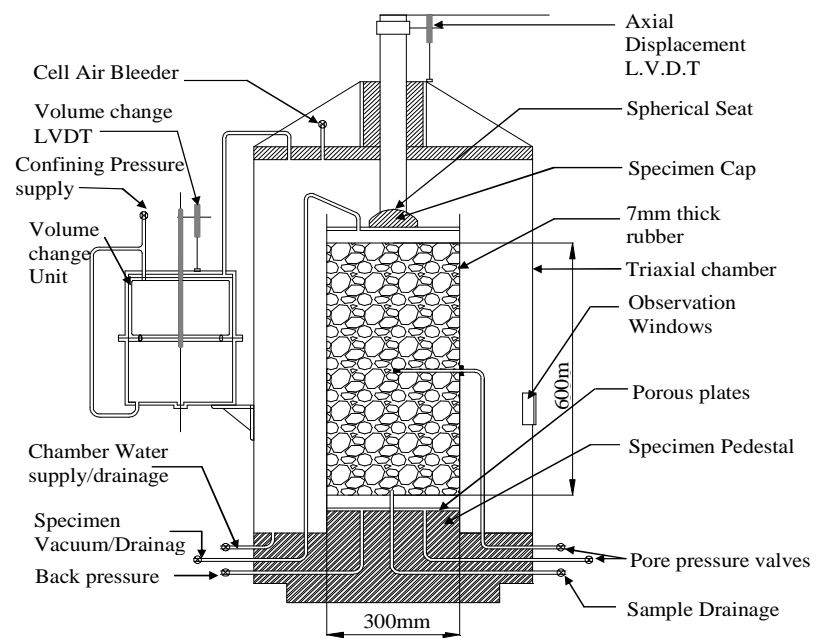

Figure 1: Schematic illustration of large-scale triaxial chamber (modified after Indraratna et al., 2012)

The initial particle size distribution, density and void ratio of ballast were kept almost identical in all specimens to capture realistic track conditions. It has been argued in past studies that as the sample size ratio (i.e. diameter of the test specimen to the maximum particle size) exceeds 6 , the sample size effects become increasingly insignificant (Marachi et al. 1972, Indraratna et al. 1993). The gradation (Figure 2) of clean ballast used in this study has the maximum grain size ranging between 50 and $60 \mathrm{~mm}$. Commercially available kaolin was used to simulate clay fouling (Figure 2).

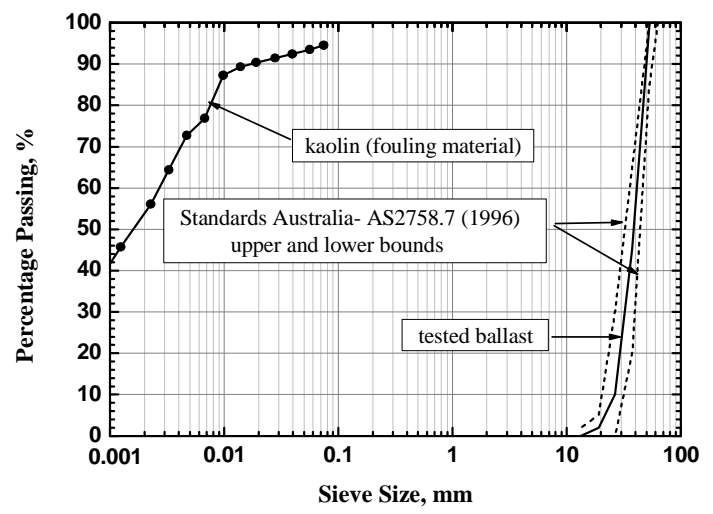

Figure 2: Particle size distribution of test materials (Modified after Indraratna et al, 2012)

When preparing clay fouled ballast specimens, the amount of clay needed for a given value of VCI was calculated for each test specimen. Then a quarter of the clay was mixed with a quarter portion of ballast using the concrete mixer, and then placed inside the upright cylindrical membrane in preparation mould. The moisture content of clay $(w=52 \%)$ during mixing was slightly larger than the liquid limit. A hand held vibrating plate was used to compact the specimen following the sequential procedure as explained before for the subsequent layers. 
After preparing the test specimen, the outer cell chamber was placed and connected to the axial loading actuator. For all the tests, back pressure of $80 \mathrm{kPa}$ was applied to obtain sample saturation with Skempton's $B$ value approaching unity $(B>0.98)$.

\section{Results and Discussion}

Figure 3 illustrates the stress-strain behaviour of fouled ballast $(V C I=10$ and $80 \%)$ in contrast to clean ballast $(V C I=0 \%)$ at increasing confining pressure.

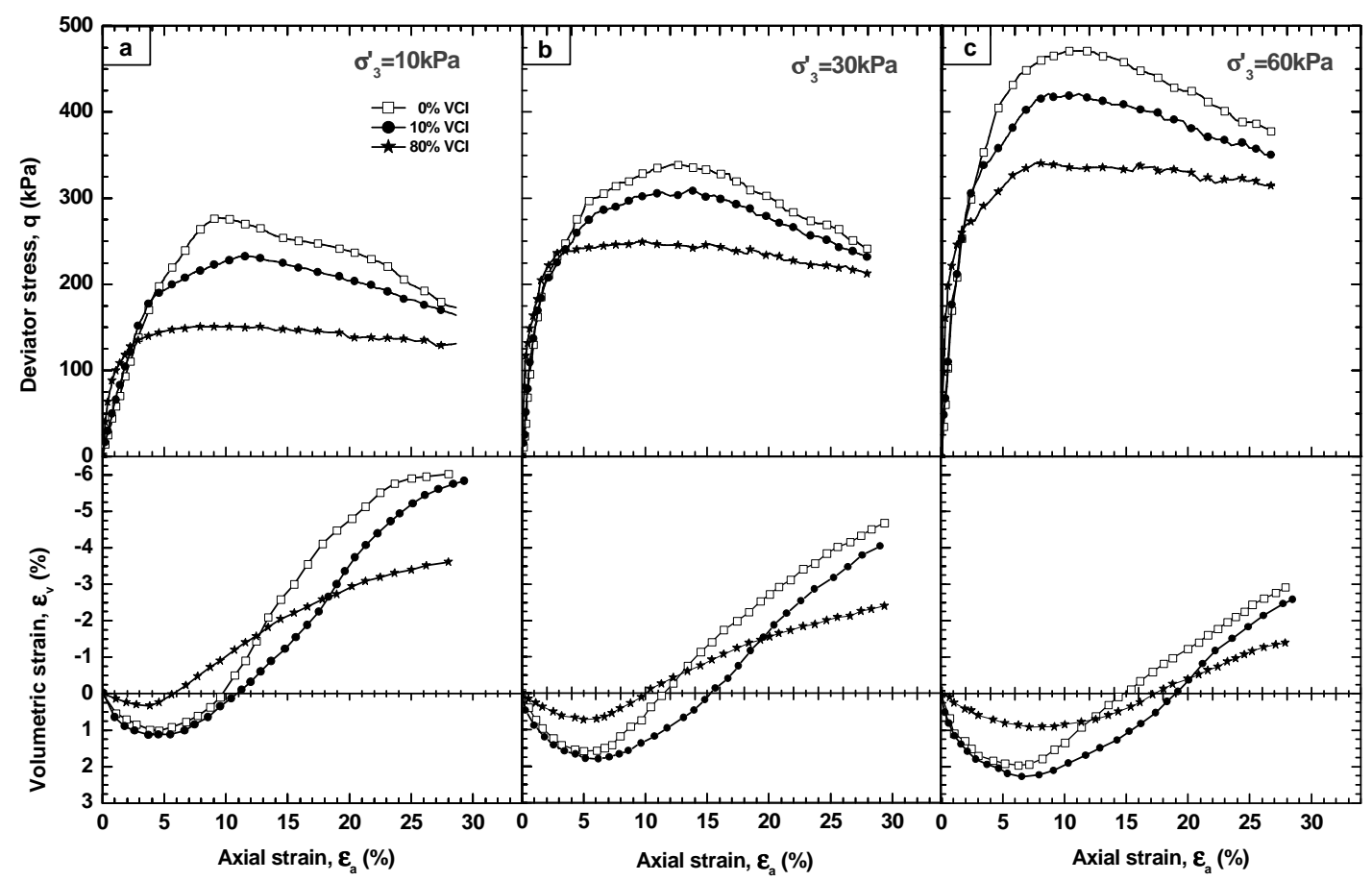

Figure 3: Stress-strain behaviour of clean and fouled ballast during isotropically consolidated drained tests at confining pressures $\left(\sigma_{3}^{\prime}\right)$ of (a) $10 \mathrm{kPa}$, (b) $30 \mathrm{kPa}$ and (c) $60 \mathrm{kPa}$, respectively (Modified after Tennakoon et al, 2012)

As expected, when VCI increases the peak deviator stress decreases significantly. The stress-strain plot for VCI $=80 \%$ shows a more ductile post-peak response. In the compression zone, the increasing VCI generally shows a reduced compression of the fouled specimen as the voids between the ballast grains are occupied by clay fouling. Nevertheless, in the case of $V C I=10 \%$, an interesting observation is noted for all three specimens (at $\sigma_{3}^{\prime}=10,30,60 \mathrm{kPa}$ ) indicating a slightly increased compression compared to their fresh ballast counterparts. This may be attributed to the small amount of clay coating the particles acting as a lubricant, thereby facilitating the specimens to attain a slightly higher compression. With respect to dilation, the highly fouled specimens show a decrease in the rate and magnitude of dilation at axial strains exceeding @ 20\%, while the increase in $\sigma_{3}^{\prime}$ from 10 to $60 \mathrm{kPa}$ significantly suppresses dilation. The addition of kaolin in sufficient quantities appears to contribute to a 'binding' effect that diminishes the tendency of the aggregates to dilate. Table 1 summaries the peak deviator stress with VCI. 
Table 1: Variation of peak deviator stress $\left(q_{p e a k, f}\right)$ with Void Contaminant Index for clay fouled ballast

\begin{tabular}{|c|c|c|c|}
\hline \multirow{2}{*}{ VCI, $\%$} & peak deviator stress $\left(q_{\text {peak }, f}\right), \mathrm{kPa}$ at confining pressures $\left(\sigma_{3}^{\prime}\right)$ \\
\cline { 2 - 4 } & $10 \mathrm{kPa}$ & $30 \mathrm{kPa}$ & $60 \mathrm{kPa}$ \\
\hline 0 & 280 & 340 & 470 \\
\hline 10 & 225 & 290 & 415 \\
\hline 80 & 150 & 245 & 334 \\
\hline
\end{tabular}

Based on the above laboratory data, the following empirical relationship representing the normalized shear strength of clay fouled ballast can be proposed:

$$
\frac{q_{\text {peak }, f}}{q_{\text {peak }, b}}=\frac{1}{1+\beta \sqrt{(V C I)}}
$$

where, $q_{\text {peak,b }}$ and $q_{\text {peak,f }}$ are peak deviator stresses for fresh and fouled ballast respectively; $\beta$ is an empirical parameter, whose magnitudes are $0.094,0.047$ and 0.05 corresponding to $\sigma_{3}^{\prime}$ of 10,30 and $60 \mathrm{kPa}$, respectively.

To calculate the maximum train speed, the method of determining the dynamic load, $\mathrm{P}_{\mathrm{d}}$ as represented by Equation 4 (Selig and Waters, 1994) is then combined with Equation 3, as plotted in Figure 4.

$$
\mathrm{P}_{\mathrm{d}}=\left[1+\frac{0.0052 \mathrm{~V}}{\mathrm{D}_{\mathrm{w}}}\right] \times \mathrm{P}_{\mathrm{s}}
$$
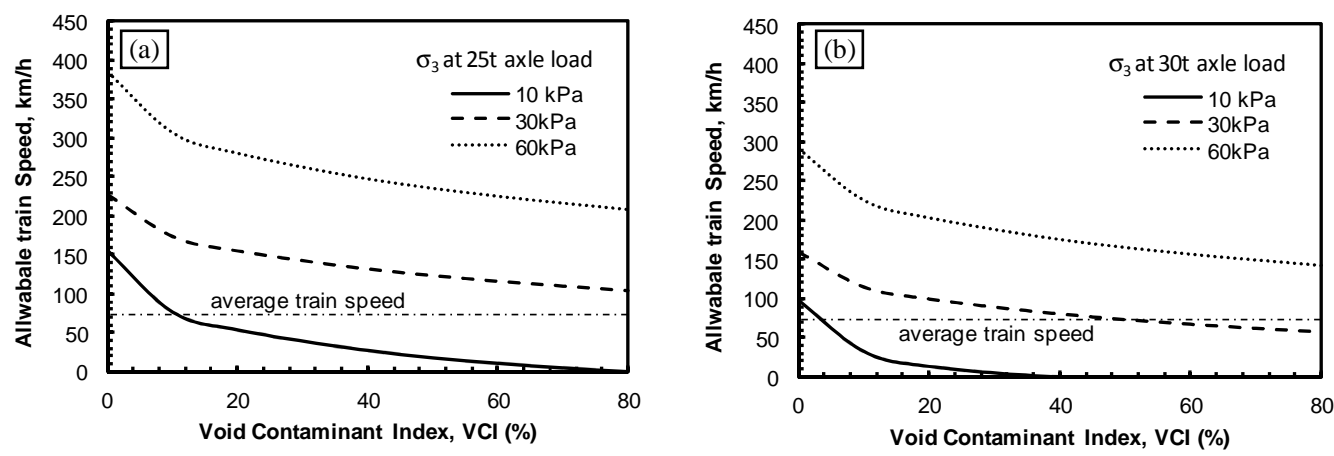

Figure 4: Allowable train speeds for (a) $25 \mathrm{t}$ and (b) $30 \mathrm{t}$ axle loads at different confining pressures

Figure 4(a) shows that at $10 \mathrm{kPa}$ confining pressure, the rail track can tolerate fouling up to $15 \%$ $V C I$ for trains with $25 \mathrm{t}$ axle load passing at an average speed of $70 \mathrm{~km} / \mathrm{h}$. However, if the confining pressure is more than $30 \mathrm{kPa}$, the track is considered to be stable at all levels of fouling. Figure 4 (b) shows that even though the confining pressure increases to $30 \mathrm{kPa}$, fouling cannot exceed $50 \% V C I$ for $30 \mathrm{t}$ axle trains moving at an average speed of $70 \mathrm{~km} / \mathrm{h}$. Nevertheless, increasing the confining pressure beyond $60 \mathrm{kPa}$ will make the track stable enough against all levels of fouling. However, achieving a confining pressure of $60 \mathrm{kPa}$ in the field is often 
impractical as this involves the use of sheet piles on either side of track or overly close sleeper spacing.

\section{Conclusions}

Proper understanding of the stress-strain-degradation behaviour of fouled ballast is important for efficient maintenance and operation of tracks. In this paper, a series of isotropically consolidated drained tests using a large-scale triaxial apparatus were conducted on clean and clay fouled ballast. Based on the laboratory test findings, a novel empirical relationship between the peak deviator stress and $V C I$ was proposed with the aim of assisting the practitioner in the preliminary track assessment. Using this relationship, the recommended maximum train speeds for fouled ballast was also proposed. The more complex aspects of clay fouling need to be carefully assessed through rigorous micro-mechanical studies to predict the performance of ballasted tracks under various levels of fouling.

\section{Acknowledgement}

The authors are grateful to the CRC for Rail Innovation for the funding of this research (Project No. R3.106). They would also like to thank the Industry partners including RailCorp, ARTC and Queensland Rail (QR National) for their keen collaboration in this study.

\section{References}

ASTM (2002). Standard Test Method for Consolidated Undrained Triaxial Compression Test for Cohesive Soils., ASTM D4767-02.West Conshohocken, PA: ASTM International.

Australian Standard: AS2758.7 (1996). Aggregates and Rock for Engineering Purposes; Part 7: Railway Ballast., Sydney, NSW, Australia.

Bishop A. W. and Henkel, D. J. (1962). The Measurement of Soil Properties in the Triaxial Test, Arnold, London.

Feldman, F. and Nissen, D. (2002). Alternative testing method for the measurement of ballast fouling, Conference on Railway Engineering RTSA, Wollongong NSW, Australia, 101-109.

Huang, H. and Tutumluer, E. (2011). Discrete Element Modeling for Fouled Railroad Ballast. Const. and Building Materials., 25(8): 3306-3312.

Indraratna, B., Ionescu, D. and Christie, D. (1998). Shear Behaviour of Rail Ballast on Large Scale Triaxial Testing. J. of Geotech. Geoenviron. Engng ASCE 124(5): 439-449.

Indraratna, B., Lackenby, J. and Christie, D. (2005). Effect of Confining Pressure on the Gradation of Ballast under Cyclic Loading. Géotechnique 55(4): 325-328.

Indraratna, B., Nimbalkar, S. and Tennakoon, N. (2010). The behaviour of ballasted track foundations: track drainage and geosynthetic reinforcement, GeoFlorida 2010, ASCE Annual GI Conference, February 20-24, 2010, Florida, USA: p. 2378-2387.

Indraratna, B., Salim, W. and Rujikiatkamjorn, C. (2011). Advanced Rail Geotechnology - Ballasted Track: CRC Press/Balkema.

Indraratna, B., Tennakoon, N., Nimbalkar, S., and Rujikiatkamjorn, C., (2012) "Behaviour of Clay Fouled Ballast under Drained Triaxial Testing." Geotechnique,

Indraratna, B., Wijewardena, L.S.S., and Balasubramaniam, A.S. (1993). Large-scale triaxial testing of greywacke rockfill. Géotechnique 43(1): 37-51.

Lim, W. L. and McDowell, G. R. (2005). Discrete Element Modelling of Railway Ballast. Granular Matter, 7(1): 19-29.

Lu, M. and McDowell, G. R. (2006). Discrete Element Modelling of Ballast Abrasion. Géotechnique 56(9): 651-655.

Marachi, N. D., Chan, C. K. and Seed, H. B. (1972). Evaluation of Properties of Rockfill Materials. J. of the Soil Mech. and Found. Div. ASCE 98(1): 95-114.

Selig, E. T. and Waters, J. M. (1994). Track Technology and Substructure Management. Thomas Telford, London.

Tennakoon, N., Indraratna, B., Nimbalkar, S. and Rujikiatkamjorn,C., (2012) "Deformation and Degradation of Clay Fouled Ballast Subjected to Monotonic Loading". International Conference on Ground Improvement and Ground Control: Transport Infrastructure Development and Natural Hazards Mitigation, Wollongong, NSW, Australia :p 1521-1527

Tennakoon, N., Indraratna, B., Rujikiatkamjorn, C., Nimbalkar, S. and Neville, T. (2012). The role of ballast fouling characteristics on the drainage capacity of rail substructure, ASTM Geotechnical Testing Journal, 35(4): 1-12. 